\title{
Navigating constricted channels: local cooption, coercion, and concentration under co-management, Mweru-Luapula fishery, Zambia
}

\author{
Christopher M. Annear ${ }^{1}$ \\ Boston University, USA
}

\section{Introduction}

In theory, natural resource governance through co-management promises a rich array of benefits for local populations, from representative decision-making to legitimately equal and open access to natural resources. Anthropologists, social geographers and other practitioners of political ecology will not be surprised to learn that such theory rarely bears out in practice, but that instead sociopolitical relationships are forged in the niches created by reoriented power structures. These reconfigured relationships exhibit not only shifts in peer networks but also in relationships of scale, for example, among local fishers and chiefs, and chiefs and government agents.

Recent application of a co-management system of enforcement in the Zambian portion of the Mweru-Luapula fishery shows how well-intentioned policy fails to produce expected results: leading to spoils for some and reduced value of access for others. This paper focuses on one among several case studies derived from this region. It describes how a small group of roughly fifty lake island residents gain advantage from the dubious legality of their incursion into a perpetually closed fish breeding area because, while legislative statute restricts all fishers from these fecund common-pool resource grounds, co-management empowers "traditional" modes of authority with the de facto clout to rebuff civil officers charged with evicting these potentially destructive occupants. For their part, the recent immigrant squatters argue a moral imperative to residence by claiming autochthony. By doing so they leverage the co-management prerogative intended to protect indigenous rights, while bolstering their own campaign to entrench themselves in the most valuable waters of the fishery.

This contingency is made possible by the imposition of co-management-itself an extension of a general shift in Zambia toward neoliberal governance over approximately a decade and a half. I focus on this case in order to better understand how practice plays out of a theoretical management structure. In particular, how this ethnically plural population responds to the constrictions and endowments presented by the comanagement model. In this article I hope to contribute ethnographic evidence showing that policy meant to decentralize and democratize decision-making among local stakeholders of common-pool inland fishery resources can act to shift regional sociopolitical power relations, while not necessarily expanding constituent voice or resource access. Theoretically, I believe that present fishing and trading politics on the MweruLuapula provide an example of shifts in scale and an opportunity to rethink Brown and Purcell's (2005) contention that political ecologists too often support local practice to provide the most sustainable and democratic outcomes for communities. Last, although this is not a journal that is specific to discipline, I wish to draw the attention of environmental anthropologists to the important contributions being made by geographers on the topic of scalar politics among common-pool resource users.

\section{Methods}

Presented and supporting data are derived from field-based participant observation and semistructured interviews; secondary published, unpublished "gray" literature, and archival sources; and a 9-12 month trio of fish market surveys. I spent 23-months in Zambia from December 2003 to November 2005. I conducted many interviews (semi-structured, most documented using handwritten notes), 11 of which relate

\footnotetext{
${ }^{1}$ Ph.D. Candidate, Department of Anthropology, Boston University, 232 Bay State Road, Boston, MA 02215; USA. Email: cannear "at" bu.edu. I acknowledge the generous support of a J. William Fulbright Fellowship, which officially funded my first 12 months of fieldwork, and a Cora du Bois Writing Fellowship, which supported part of my dissertation completion. I was a research affiliate of the Institute of Economic and Social Research at the University of Zambia for the duration of my fieldwork. This article, as is the case with most if not all works of scholarship, is the product of many minds. Although I am the credited author (and solely responsible for flaws in thought and execution), I want to thank my doctoral advisory committee: professors James A. Pritchett, Parker Shipton, James C. McCann, Les Kaufman, and Robert P. Weller. In addition, I owe intellectual debts to professors Michael J. Sheridan for improving my understanding of autochthony, David M. Gordon for his superb historical scholarship of the region and unfailingly helpful and supportive comments, and Timothy Collins, Simon Batterbury and anonymous reviewers for their suggestions concerning geographical treatment of the politics of scale. This paper is part of the 2008 Eric Wolf Prize special feature, edited by Timothy Collins and Josiah Heyman.
} 
directly to this subject matter. However, specific insights concerning relationships among Kanakashi residents, Lunda chiefs and Department of Fisheries officials were most often the products of casual conversation and observation. I conducted surveys of three fish markets in Nchelenge District in 2004 to 2005. Quantitative and qualitative data (e.g. fish species, numbers of individuals, tip-to-tail length, fish trader comments) were recorded 3 times each week at each market for the open fishing season (March to December). Due to concerns over illegal fishing, I was only able to record data during the annual closed fishing season (December through February) in one of these three markets. Zambians recorded all information, but made sure to explain my role as researcher and the intended use of the data.

\section{Kanakashi Island}

As viewed by most, residents of Potolo Village reside illegally on the island of Kanakashi, which is located within the Mifimbo Fish Breeding Area of Lake Mweru (Figure 1). Although there is no explicit prohibition to settlement on the land itself, fishing in these environs is banned year round. ${ }^{2}$ Since 1948 , Mifimbo has been designated by law as a perpetually closed fishing area due to its value as a breeding site for fish throughout the Mweru-Luapula ecosystem. ${ }^{3}$ It is variously referred to as the "mother," "womb," "child," and "granary" of the fishery due to its fecundity as a breeding ground for several of the fishery’s most valuable commercial species. Catches in Mifimbo are on average triple that of the most robust takes reaped in other areas of the fishery (P. Zwieten and C. Kapasa 1995).

The earliest settlers to Kanakashi Island arrived between 1935 and 1937, ${ }^{4}$ yet it is only over the past two decades that fishers have begun to colonize the island in significant numbers. There is little ecological defense for residence on Potolo, Kanakashi's largest and most politically organized village, yet inhabitants argue vehemently for their right to live on the island. Despite being widely identified as a major cause of hastened fish stock decline, Potolo villagers have thus far successfully avoided eviction through the manifold strategies of forging expedient political relationships with regional traditional leaders; claiming autochthonous status and a role as ecological conservators; and, perhaps most effectively, by building community.

Kanakashi residents are enhancing their self-imposed claim to this land by employing development discourse and building community infrastructure, while simultaneously insisting on their role as modern autochthons-traditional defenders of a vital resource. In reference to this last guise, several long-term residents recently established the Mifimbo Traditional Fishing Association, which they claim is an officially recognized organization. ${ }^{5}$ Political organization also includes activities such as the lobbying of local politicians and mainland-based traditional rulers, as well as frequent initiatives to forge an alliance with the Zambian Department of Fisheries (DoF) — the authority charged with evicting them from Mifimbo.

These tactics notwithstanding, local opinion stands near unanimously against residents of Potolo Village and elsewhere on Kanakashi Island. Some voice particularly vociferous resentment of these fishers because they are perceived to be "killing the child." ${ }^{6}$ Although law and public judgment equally condemn settlement on land encompassed by the Mifimbo Fish Breeding Area, these fishers have managed to maintain residence. One of the questions central to this inquiry is simply: if fishing in Mifimbo is patently destructive, broadly condemned, and illegal, why have sundry government and traditional authorities, and other fishing interests all failed to evict these settlers from Kanakashi Island?

I argue that the circumstances that allow ongoing residence in Mifimbo are made possible by the ambivalent juxtaposition of two ill-fitting management schemes. The settlers' persistence is due to their ability to exploit the ambiguous political and socioeconomic space that exists between the two currently available management options for the Mweru-Luapula fishery. These are the top-down enforcement mandated by law and its theoretical complement, the locally rooted alliance between the traditional authorities and the government known as "co-management" (H. Aalst 1999).

\footnotetext{
2 Relevant law: Statutory Instrument 198 of 1986; Subsidiary Legislation of the Fisheries Act, No. 13, 1994, Chapter 200 (1974), Laws of the Republic of Zambia.

${ }^{3}$ This legislation was absorbed into the Fish Conservation Act, Chapter 263 of 1955, Laws of Northern Rhodesia. For a discussion on the evolution of this act see Annear 2006.

${ }^{4}$ Fieldnotes and interviews conducted by the author confirm that people initially settled on the island during this era. Comments made by fishers at a meeting held by the Senior Chief of the Lunda-Kazembe, the Mwata Kazembe Mpalumena XIX, concerning the Mifimbo Fish Breeding Area specifically stipulate this date range (Kafumbe 2005).

5 The vice-chairman of the Mifimbo Traditional Fishing Association claims that Mwata Kazembe Mpalumena XIX extended it official status as a fishing association in 2005 (interview, October 2, 2005, Potolo Village, Kanakashi Island.) In addition to this group, three, possibly four, branches of the Mweru-Luapula Fishing Association are also recognized and active on the island. Chongo et al. (1995) documents two branches in Kanakashi and one in Potolo villages, respectively, while Zwieten et al. (1995) records one in Kanakashi and another in Mwitwa Village, Kanakashi Island.

${ }^{6}$ This is a common idiom that references both fishing in a breeding area and catching pre-reproductive age small fish and fry using nets with illegally minute mesh-sizes.
} 


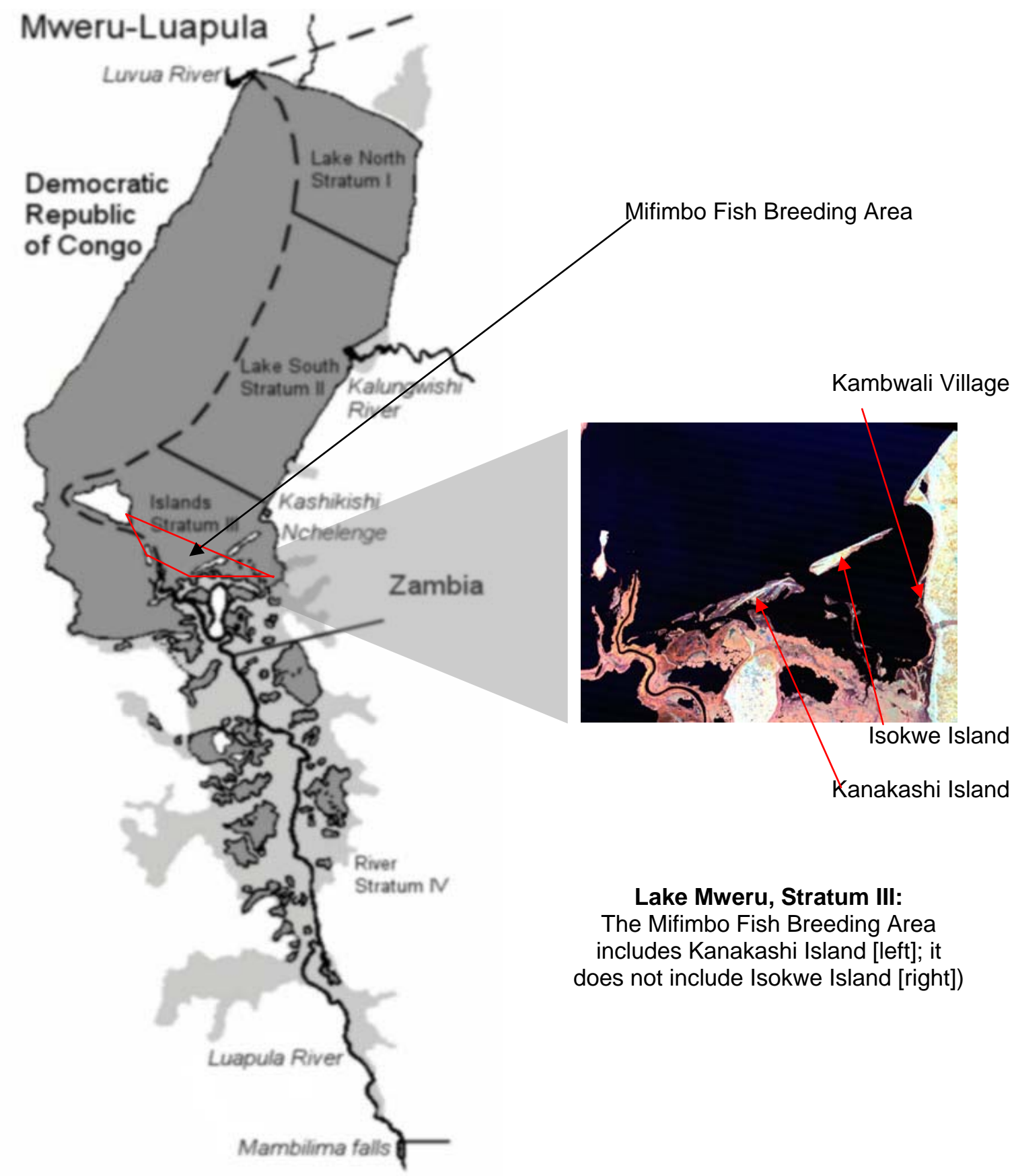

Fig. 1. The Lake Mweru-Luapula ecosystem, Mifimbo Fish Breeding Area, and Kanakashi Island. .Sources: Zambia Department of Fisheries, and Satellite Image, False Color p172r67_5t890602.

\section{Politics of Scale and the "Local Trap"}

The introduction of co-management into Mweru-Luapula governance structures follows the tide of structural adjustment, economic liberalization, and decentralization of state powers that began with the election of President Frederick Chiluba and the ushering in of the Zambian "Third Republic" in 1991. Although the draft legislation that would make co-management official has not yet been enacted into law, 
regional chiefs and government officials have largely accepted the spirit of the intended changes (R. Lubilo et al. 1993; B. Aarnink and C. Kapasa 1995; F. Kafumbe 2005). Restructuring of fishery management via co-management makes most sense when combined with its attendant assumptions. The first is the expectation of fishery collapse, otherwise known as the tragedy of the commons (see below for discussion). Despite the existence of clear data that should disabuse people of this supposedly inevitable trajectory, most still presume that this is the reason that stronger state power is needed.

Political ecologists and others counter this demand for more robust top-down governance by arguing that local problems require local solutions. Or, more explicitly, that local control over resources is "key to environmental sustainability, social justice, and democracy." Brown and Purcell (2005: 608) call this the "local trap" in research and practice. It is a result, they contend, from political ecology's inadequate attention to the politics of scale. Co-management seems to satisfy both of the above assumptions. Increased local control allied with state laws should lead to more effective and participatory management. My data, however, suggests otherwise. Instead, co-management has enabled a reconfigured political waterscape, though not necessarily a more equal and democratic one.

Scale, in other words, is not the definition or cause of a desired outcome. Rather, it is a strategy applied by political groups_-in this case Kanakashi Island residents_- to pursue an agenda. This case study shows that savvy local residents recognize and exploit this new structural paradigm for governance for their own political purposes. These purposes, moreover, may not align with goals of ecological sustainability or egalitarian access.

\section{Ecological resilience, commercial problems}

Although the Mweru-Luapula fishery has recently been shown to be at less risk of an ecological crash than previously thought (P. Zwieten et al. 2003), commercial options for its occupants have narrowed appreciably over time. While the recent rise of the Chisense (Lake Sardine, Microthrissa moeruensis) industry keeps the overall fishery economy afloat (B. Aarnink 1996; D. Gordon 2005), it requires appreciable investment in order to access its markets. From 1990 to 2000 the Mweru-Luapula region has experienced roughly twice the rate of immigration as other districts in Luapula Province and the country as a whole (CSO 2004). The fishery's capacity for resilience has allowed it to absorb economic refugees seeking welfare in a shrinking formal economy, but the current fishing outposts in Mifimbo belie its ongoing commercial health. Furthermore, despite a general consensus that residence on Kanakashi adversely affects fishery production, an inability to resolve the situation exposes inadequacies in both legal enforcement and persuasion by traditional authorities (i.e. through co-management). Finally, from the perspective of the Kanakashi fishers, success is built on the literal and figurative bricks-and-mortar of community and patron-client political ties with local chiefs. In this manner, destructive fishery practices notwithstanding, Kanakashi based residents express a modern revival of the modus for past group settlement: community as defense.

Before directly considering these issues, however, the ecological fishery itself must be characterized. While law, settlement, and autochthonous rights come to the fore in debate, all rest upon the behavior of the highly dynamic Mweru-Luapula ecology. There is a close correlation between fish stocks and lake-river water level (itself a function of inter-annual rainfall), which in turn directly affects the economic wellbeing of fishers and fish traders. The next section describes how fundamental misunderstandings by the British colonial government about this and other ecological relationships has led to contemporary fishery legislation. After comment on basic socioeconomic distinctions in fishing effort, I will return to the Kanakashi Islanders who have learned to exploit these inherited colonial laws and the neoliberal co-management scheme to successfully tap into one of the few remaining commercial fishing waters of the Mweru-Luapula.

\section{Mweru-Luapula Ecology}

The Mweru-Luapula fishery spans the latitudes $8^{\circ} 30^{\prime} \mathrm{S}$ to $9^{\circ} 30^{\prime} \mathrm{S}$ and longitudes $28^{\circ} 15^{\prime} \mathrm{E}$ to $29^{\circ} 10^{\prime}$ E. It is shared by Zambia and the Democratic Republic of Congo, each controlling 58\% and 42\%, respectively. Mweru is a relatively shallow lake with a mean depth of 2 meters in the south, 3 meters in the north, and 27 meters at its greatest depth. North to south it spans approximately 74 miles (119 km) while broadening to 30 miles (48km) wide (A. Bos et al. 2006; T. Carey 1965). The Luapula and Kalungwishi Rivers flow into Lake Mweru from the south and northeast, respectively, while the Luvua River flows out from the north. It is due to this lake-river composite that Mweru is termed to be an allotrophic riverine lake, which categorizes it as a pulsed or seasonal system. Among the more striking characteristics of such a system is its inherent instability. It is governed by periodic inputs or "pulses" of nutrients, thereby causing it to be especially fertile and nutrient-rich in certain seasons and years but not others (E. Jul-Larsen et al. 2003). Such an ecological temperament endows resiliency, but also makes it particularly vulnerable to broader climate trends that affect inter-annual water levels.

Lake water level, which depends on rainfall, correlates positively to nutrient levels and therefore fishery production in Lake Mweru. Activity in the fishing sector (i.e. numbers of fishers and fish traders 
active in market exchange) can therefore be expected to increase in proportion to the periodic high fishery yields, which in turn are associated with good rains. Similarly, the livelihoods of individuals and communities that depend on this inland fishery may be severely threatened by the changes in precipitation patterns that many climate change studies observe or predict (e.g. N. Fauchereau et al. 2003; M. Hulme et al. 2003).

As stated by Jul-Larsen et al (2003: 58), "The most conspicuous external drivers of nutrient inputs... are long-term, inter-annual and seasonal fluctuations in water level and river inflow." Relative lake level fluctuation indices should therefore theoretically predict lake nutrient levels and fish stock density. Two interrelated human social problems arise from the inherently high variability of such a pulsed system. One stems from the deterioration or loss of complementary productive alternatives to fishing, and the other, the vulnerability of the fishery in cyclically lean years to overfishing. In high fertility years the MweruLuapula can sustain intensive fishing pressure (E. Jul-Larsen et al. 2003), but becomes vulnerable to excessive and targeted effort during extended periods of poor production.

\section{Volatility in God's fishery: It's the government's fault}

Continued residence for Kanakashi Islanders is not only a function of political connections. It is also the result of accumulated factors leading to a growing divide between commercial and subsistence fishers in a durable though highly variable fishery. Since Mweru-Luapula is an allotrophic ecosystem that is sensitive to rainfall and water level, it exhibits robust biological resiliency in many respects, even though overfishing has driven several species to regional extinction (D. Gordon 2006; M. Musambachime 1981). Nevertheless, grave warnings of its productive and ecological demise have been projected since the 1930s (C. Annear 2006; D. Gordon 2006).

Fearful of a "tragedy of the commons," fisheries biologists, politicians, and academics have routinely inferred a positive relationship between apparently declining (often variable) catch rates and fishery collapse. Since Garrett Hardin published his highly influential article in 1968, common-pool resources have been associated with tragedy. In it he describes an inflexible circumstance: human nature being what it is, will lead to too many individuals subtracting from an unrestricted resource, each for his own gain (G. Hardin 1968). The result is axiomatic: users will denude the resource until it can no longer regenerate.

Since then, scholars have illustrated a mosaic of alternatives to this teleology of catastrophe. Crowe (1969) asserts that Boserupian technological advancement will buy time, but, in line with Hardin, agrees that the only long-term solution lies with top-down management and scientific monitoring. Rappaport (1984) and Vayda and Rappaport (1968) articulate eco-functionalist systems that compel individuals to act for the betterment of the group, not merely for themselves. Taking a different tack, contributors to McCay and Acheson's edited volume, The Question of the Commons (1987), upend Hardin's underlying presupposition. They show through a variety of rich ethnographic examples that expectation of collapse of the unmanaged commons is premature because most resources of this kind are actually managed. Feeny et al (1990) take this analysis another step forward by advocating for a more complete theory of common-pool resources that includes institutional and cultural factors. Following a more institutionalist approach, Ostrom (1990) surveys a broad array of cases and concludes that yes, some resources may be cooperatively managed, although others cannot. She suggests that small-scale, ethnically homogeneous communities tend to cooperatively manage their resources most effectively. Others, notably, Singleton (1998) shows how under these institutional and cultural circumstances, co-management may be implemented to extend participatory decision-making among stakeholders.

As it pertains to the Mweru-Luapula fishery, Zwieten et al (2003) expose the teleology of the "tragedy of the commons" from a biological perspective, while Gordon (2005) argues its fallacy in terms of socioeconomic production. Each of these studies draws from Brox’s (1990) assertion that Common Property Theory is an analytical rather than empirical model and is therefore an inadequate diagnostic and application tool for fishery management. Furthermore, empirical research unbiased by this Malthusian paradigm may lead to insights including the capacity of inland fisheries to absorb under-capitalized economic migrants without overwhelming the ecological system (O. Brox 1990, D. Gordon 2005).

Despite these recent corrections, Malthusian thinking has been the impetus and foundation for 90 years of colonial and postcolonial legislation of Zambia's fisheries. The central focus of these laws therefore continues to enable formal commercial fishing effort as the solution to perceived over-fishing, while condemning informal and non-market subsistence activities as its cause. The specific laws intended to regulate the Mweru-Luapula fishery are drawn almost word-for-word from the Fisheries Act enacted in $1974,{ }^{7}$ which, in all intents and purposes merely rewrites the same rules found in the colonial Central African Federation era Fish Conservation Act of $1955 .{ }^{\circ}$

\footnotetext{
${ }^{7}$ Cap. 200, 1974

${ }^{8}$ Cap. 263, 1955.
} 
Although the Mweru-Luapula fishery is more resilient than long thought, it periodically does experience intensive and specific fishing pressure, which tends to consume fishery resources unevenly and promote ecological and market fluctuation. The demise of the Luapula Salmon-largely at the Luapula River mouth where it swam into nets that stretched fully across its spawning path-is the most infamous but not the only example of such excessive targeting.

Fishing pressure is, of course, particular to the needs of the fisher. The two most general socioeconomic categories of fishers in the Mweru-Luapula are those who fish commercially, and subsistence "for the pot" fishers. The majority of subsistence fishers access the fishery via the banks of the Luapula River, while contemporary commercial enterprise tends to be restricted to Lake Mweru (Zwieten et al. 1995). The Mifimbo Fish Breeding Area connects these two zones ecologically and economically. Despite its geographic proximity to each productive area, Mifimbo is exploited for commercial, but not subsistence purposes.

Such inconsistency and inefficacy of the law ultimately served to create an apparently impossible dilemma for fishery management. Whereas, local Department of Fisheries officials were unable to enforce legal mandates prescribing how and where people fished in Mweru-Luapula, they were also blamed for the widespread perception of diminishing stocks of fish. While Luapula fishers, fish traders, and traditional rulers all attribute fishery fecundity and variations in weather to God, the blame for insufficient fish stocks, they charge, must be borne by the Zambian government. On a practical level, top-down fishery resource management in postcolonial Zambia suffers from under-capacity and a surfeit of responsibility. It was with this recognition that the concept of "co-management" was introduced in the 1990s as a means of integrating traditional authorities more effectively into the enforcement effort.

\section{Co-management}

In theory, co-management redresses decades of government ineffectiveness and over-fishing by empowering local traditional leaders and other constituent actors in the fishery with decision-making authority. The concept was introduced ${ }^{9}$ in 1993 by the Netherlands Development Organisation (SNV) and the Zambian Department of Fisheries (H. Aalst 1999). Although it has not yet reached official implementation, co-management has achieved de facto recognition through a series of workshop events (R. Lubilo et al 1993; B. Aarnink and C. Kapasa 1995; F. Kafumbe 2005) and the absence of effective government management.

Its structure follows Western-inspired neoliberal trends encouraged in many African countries since the early 1990s of democracy, decentralization, and economic liberalization. Co-management reflects these values by extending representation to the outer tendrils of the fishing effort through a political network that connects fishers and traders to a representative central decision-making body via local fishing associations, wards, and districts. As imagined, the Central Advisory Committee should then act as the council of representatives who support the interests of their constituents in regards to fishery-wide management and enforcement duties.

In practice, however, neither the central committee, nor any of its local groupings have been created. Instead, an informal co-management relationship has emerged in several sectors of the fishery in modes and styles that suit local needs and interests. In the Mifimbo Fish Breeding Area and proximal environs, it is the Department of Fisheries and several customary leaders who comprise the core of this unofficial comanagement. One Lunda chief in particular has positioned himself to be the power broker connecting the government (via the Department of Fisheries) to fishers, especially those plying their trade in the Mifimbo Fish Breeding Area. The co-management institutional prerogative presupposes that traditional leaders as a category may assume greater responsibility for natural resource management than was permitted during colonial and past postcolonial periods. In practice, Sub-Chiefs ("chiefs" in common parlance) rule over headmen, but under Senior or Paramount Chiefs, are expected to enforce those laws the Department of Fisheries lacks the funding and manpower to police. However, increasingly, chiefs such as the Mwata Kambwali $^{10}$ have appropriated co-management directives to claim greater authority to pursue their own initiatives. One result of this relationship of expediency is to mollify development practitioners and national government officials. In practice, however, all it does is to maintain the inefficacy of top-down governance and simply shift the concentration of power from civil to customary governance. These restructured power dynamics present opportunities to midlevel players, such as those people living on Kanakashi Island, to rescale resource control and de facto governance for their benefit. This will be discussed further after a brief description of the fishery economy.

\footnotetext{
${ }^{9}$ Although not enacted: a novel Fisheries Act, which set out the structure and conditions of co-management, was drafted in 2001. However, to present it has not been made into law.

${ }^{10}$ Mwata is the Lunda title for a ruler. The Mwata Kambwali resides on the Lake Mweru shoreline, east of Kanakashi, and rules over an area that includes the island.
} 


\section{Mweru-Luapula Socioeconomy}

The contemporary fishing industry of Mweru-Luapula is almost exclusively artisanal, meaning that fishing is small-scale, low in productivity, and its operations tend to include meager to modest capital investment. ${ }^{11}$ Since the onset of colonial rule at the end of the $20^{\text {th }}$ century, Mweru-Luapula has varied from operating as a common-pool to de facto open-access resource (Dietz et al 2002: 18). ${ }^{12}$ During colonial rule, Greek and other expatriate fishing operations were encouraged by legislation favorable to the establishment of capital-intensive monopolies to mediate nearly all access to the commercial fishery. The postcolonial period witnessed a reaction against this singular channel for exploitation, which has continued to support a popularization of resource access. Today, virtually anyone who can travel and even temporarily reside by the lake-river system may venture into its waters to catch, purchase, and/or sell fish. Unlike other land and water bodies in the region where government and traditional rulers exert restrictive tenure, Mweru-Luapula today exhibits virtually unhindered access to any individual with the economic wherewithal to exploit its resources. This modern circumstance has developed over the past fifty years as a consequence of a high rate of inmigration, a legacy of colonially undermined traditional authority, and improved transport networks that enable anyone to catch and ship fish to industrialized central markets.

Labor in the contemporary Mweru-Luapula fishery is highly segregated by gender, age, and gear ownership. Boat and gillnet owners tend to be male and over thirty years of age. Although the percentage of women who own fishing gear is increasing, there are at least twenty men to every woman (P. Goudswaard 1999). This discrepancy is particularly broad in Lake Mweru, where there is a relative dearth of shoreline docks needed by boats with gear, compared to the Luapula River where gearless fishers access the water. Those fishers who do not possess gear have two options in the fishery: to hire out their labor, or to use her basket or seine net to fish in beach areas close to fish stocks. In practice this means young men sell their labor as fish hands, and women comprise nearly nine out of every ten subsistence fishers (P. Zwieten and C. Kapasa 1996).

In possession of gear or not, actively "killing"13 fish is considered a masculine activity. Furthermore, older men who can afford to avoid the hazards of fishing on the open water will choose instead to employ younger itinerant workers. Therefore, most fishers who venture onto the lake for commercial purposes water are young and male. Fishing can be grueling, unprofitable, and, too frequently, lethal, due to highly variable weather and lake conditions.. Thus it is not surprising that most found on the water are those who possess few other options to earn a livelihood. Often unmarried and transient, young men work on boats owned by others for shares of the prospective catch. These fishery laborers are known as fish hands (abatiana) or derisively as bankungulume, after the Zambian bachelor copper miners of a generation past.

Despite their low economic and social status, fish hands and similarly positioned boat-transport operators nevertheless appear as the fishing industry's public face. Usually adorned in fashionable replicas of American basketball and British soccer jerseys, these young men conspicuously represent the modern Mweru-Luapula fishery's underlying economic logic. They typically realize minimal profits from the share system, so they often continue fishing after ecologically appropriate yields have been exceeded. Although the financial rewards are meager from this difficult and dangerous work, fish hands disproportionately jeopardize the fishery commons because they earn their modest incomes at the expense of marginal and vulnerable fish stocks.

As men and boys dominate the occupation of fish hand and gear ownership, local fish trading has become the domain of women and girls. Once transferred from boat to basket and male to female, fishmany still using their auxiliary breathing organs in a struggle for oxygen-become transformed from living organisms to marketable commodities. Local traders, almost exclusively women, are known with a snicker as banamakupwila for the act of shoeing flies from rotting fish in hot, sunny markets. From shoreline points of sale, these women link the fishery to markets, locally and throughout the region.

Among fish traders, marriage status constitutes a significant delineating factor. Married women, whose husbands have stable employment as teachers, farmers, or civil servants, may work as traders to

\footnotetext{
${ }^{11}$ Worldwide there are likely over 20 million fishers in this category. However, a number can only be approximated as such fishing practice is often overlooked in favor of larger, more mechanized fishing operations. Furthermore, within the scholarship on artisanal fishing industries generally, data and description of inland fisheries of this type tend to be scant compared to coastal industries (Marshall et al 1975, Charles et al 1993).

${ }_{12}$ This working definition of common-pool and open-access resources in full: "A common-pool resource is a valued natural or human-made resource or facility that is available to more than one person and subject to degradation as a result of overuse. Common-pool resources are ones for which exclusion from the resource is costly and one person's use subtracts from what is available to others. The diversity of property rights regimes that can be used to regulate the use of common-pool resources is very large, including the broad categories of government ownership, private ownership, and ownership by a community. When no property rights define who can use a common-pool resource and how its uses are regulated, a common-pool resource is under an open-access regime" (Dietz et al. 2002: 18).

${ }_{13}$ Direct translation of the Chibemba verb ukwipaya, which is the primary action executed when fishers locate and catch fish.
} 
supplement household income. Even if married to fishers, some women remain independent entrepreneurs financially and logistically, often eschewing their husbands as business partners for other fishers who provide their source of fish. As traders, women frequently out-earn their fish-hand spouses. Locally, neighbors mock such couplings; referring to the husband as having been married (aliupwa; passive verb construction) by his wife, rather than vice versa. Unmarried fish traders face quite different occupational circumstances. With fewer lateral social obligations, potentially they can earn and keep more of their profits than their married counterparts. However, these women are said to "only have their fish"; meaning that they are fully invested in buying and selling fish, with few reserves to draw upon in the case of personal misfortune or a long stretch of bad weather.

\section{Chibalebale: Fishing for subsistence}

The term chibalebale is the recent linguistic invention coined to describe the ecologically destructive product of catching and selling assorted juvenile fish. While it may seem like a symbol of wholesale fishery collapse, as has been predicted by neo-Malthusian alarmists, instead, it is a symptom of uneven fishing pressure in an economically stratified system. It refers not to single species, but rather to the quantity of fish being sold. It translates literally as a "thing in a dish"; meaning assorted juvenile fish sold by the small dish or bowl full, for the US\$ equivalent of 10-20థ. A serving typically includes various species of juvenile fish, haphazardly collected in nets with illegally small mesh-sizes well before they reach reproductive age. When fishers catch and local customers purchase chibalebale, in effect they consume the potential of many future fish stocks.

Chibalebale is a primary subsistence food source for the majority of fishers and traders who are either too under-capitalized to enter the commercial fishery or completely invested in the daily market turnover (e.g. female fish traders who "have only their fish"). Many Mweru-Luapula residents report having not once consumed large, commercial varieties of fish for the past five or even ten years, because these species had become either too expensive or too valuable as saleable commodities. ${ }^{14}$ Fishing for chibalebale is illegal; the minute mesh-size nets necessary to catch such tiny fish are prohibited. However, subsistence fishing of this nature goes unpunished, because fishery officials and traditional authorities alike feel they cannot begrudge people this important food source. Although illegal by law, chibalebale is a fishing activity that is tacitly permitted, largely as a function of its relationship to co-management. Due to the increasing inconsistency in recent times of large fish catches for commercial markets and the recent endowment of at least rhetorical management power given to traditional authorities through co-management, such fishing is given social, if not legal, sanction by chiefs. Another activity that is statutorily illegal, but locally tolerable is settlement on Kanakashi Island in the Mifimbo Fish Breeding Area.

\section{Kanakashi Island: Settling for commerce}

The colonial Northern Rhodesian Parliament officially recognized the richness of the Luapula River mouth, called the Mifimbo Fish Breeding Area in 1948 by outlawing all fishing activity within its stipulated boundaries. $^{15}$ It is the breeding home for several commercial species, including two that are of particularly high value: the Green-headed Bream (Oreochromis macrochir) and the Red-Breasted Bream (Tilapia rendalli). In addition to government officials, traditional authorities evoke the significance of this area through the use of such reference terms as "mother of the fishery" and "granary." Many of these leaders also declare their support for the permanent fishing ban, especially when speaking in their capacity as "comanagers" of the fishery (F. Kafumbe 2005; R. Lubilo et al. 1993). Public pronouncements notwithstanding, the actions of a few chiefs have greatly strengthened the position of communities of people who have moved into Mifimbo as far back as seventy years, but in greatest numbers over the past two decades. Not surprisingly, residents of Kanakashi Island, located entirely within Mifimbo, argue that they should not be evicted. They plead that they have earned unencumbered residence on the island through precedence and permanence of settlement. Additionally, they plead that if they were to be removed it would simply clear the way for unscrupulous Congolese fishers to immigrate into the area. In support of this argument they make

\footnotetext{
${ }^{14}$ Comments solicited from fishers and traders throughout 12-month, 3 market survey conducted by the author in Nchelenge boma and Kashikishi and Ntoto villages, 2004-2005.

15 "That portion of water of Mweru bounded by a straight line drawn form the northern tip of Nkole point in a northerly direction to the southernmost tip of Kwila (sic) Island; thence in a south-easterly direction to the bank of the Chota channel; thence following the shores of Lake Mweru to the right bend of Luapula River; thence up this River for a distance approximately 5 kilometers; thence to the nearest boundary between Zaire and Zambia opposite; thence in a northerly direction along this boundary to the point of starting the rest of that area" (Fisheries Act Cap. 200, No. 21 of 1974).
} 
frequent attempts to assert quasi-official status, as expressed in one letter in which they propose to act as the "eyes and hears" for the Department of Fisheries. ${ }^{16}$

Kanakashi residents appropriate the rhetoric of tradition and conservation when arguing for the right to maintain their settlements into perpetuity. In practice, their most effective tactic for seeking public recognition is the formation of community and infrastructure. Although law is unsympathetic to social organizations, co-management is not. Even though the co-management scheme has not been officially implemented, its logic holds sway. In 1995 senior Mweru-Luapula fisheries officials discussed just this point in a document that laid out the possibilities for managing settlement in Mifimbo. In addition to the alternatives of willfully ignoring the settlements or, conversely, increasing enforcement efforts, they surmised that,

[Another] option is to give fishing rights to fishers or to start a community based management programme... This will certainly improve the contacts between (some of) the settlers and the Department [of Fisheries]. However community based management is a rather new concept and not easy to understand or implement....But in the first place it requires a cohesive community. And this is exactly what is not there in Kanakashi" (DoF 1995: 2; emphasis in original).

Kanakashi villagers clearly understand the power of community formation as a means toward the achievement of official recognition. A visitor to Potolo, Kanakashi's most vibrant village, sees this initiative immediately. Some shelters mostly older ones, suggest a transient fishing settlement: sleeping quarters are roughly erected using locally available reed and grass thatch; several of these shacks stand roofless; and fishers sleep without bedding on the ground. But today, these rudimentary structures are less numerous than the growing number of houses on the island constructed using brick and concrete. As opposed to the reed structures these brick houses evoke a sense of momentum toward permanency.

This is, of course, by design; but it is a slow process. Brick construction is consuming of labor and time. In order to build with bricks, residents must first paddle them to the island. Since only a small quantity of bricks can be transported on any given trip, many buildings remain only partially complete, exposed to the wind and rain. In addition to building private houses, Potolo residents have managed to civilly and politically embed themselves on sandy Kanakashi Island. In 1986 they procured a government concession for a school charter, and have recently completed construction of a brick schoolhouse with an iron-sheet roof. They also became a government polling station in 1985, although government officials remain wary of collecting their votes while on the island.

The Potolo community is comprised of about fifty declared permanent residents and two to three times that number when augmented by transient fishers. It is young (average age: 39 years), ethnically heterogeneous - and conspicuously growing. The chair of the Mifimbo Traditional Fishing Association is only in his 40s, and residents talk about a local spirit medium who has control over lake winds and ancestral shades. Despite his deep knowledge and local power base, this spiritualist is said — without a hint of ironyto have immigrated to the island only in the past thirteen years. On Kanakashi, history is shallow: seventy years makes a claim for autochthony, forty years ages an elder, thirteen a mystic, and a few years apparently is enough to make a bid for permanent settlement through the erection of brick houses.

Despite the local ingenuity underway on Kanakashi Island, the question still remains as to why the government has not removed these residents from this closed fishing area. The answer lies in how the actions of these islanders relate to current management of the fishery. Although it appears to be in the interest of all fishery stakeholders that a fecund breeding area remains uncorrupted by direct fishing pressure, many cannot wait for large commercial fish stocks to breed. Overall production in the Mweru-Luapula fishery shows hopeful ecological resilience and the economic health of the Chisense industry is robust. That said, the most directly accessible commercial industry for most fishers and fish traders remains the large fish market. After at least eighty years of declining Catch per Unit Effort (CPUE) as shown in statistics, demand for the Green-headed and Red-breasted breams appears to have outstripped supply. Surveys in Nchelenge and Kashikishi, the two markets in closest proximity to Mifimbo, tally reasonably good catches of these two species; yet another market, only ten kilometers north registers virtually none. ${ }^{17}$ Qualitative evidence indicates that much if not most of these catches were derived from Mifimbo.

\footnotetext{
${ }^{16}$ E.g. Letter from Kanakashi Island residents to the Department of Fisheries, September 3, 2004, Nchelenge. Interview with Headman Shinjoni, September 6, 2004, Stated here as written. Kashikishi; Interview with Mwata Kazembe, October 9-10, 2005, Mwansabombwe; Lubilo et al 1993; and Kafumbe 2005.

${ }_{17}$ These are preliminary results of ongoing calculations of catch and price data from these markets surveys conducted by the author.
} 
Especially now that local chiefs have been granted greater power to manage the fishery, there appears to be a conflict of interest. If the waning large fish commercial industry is significantly bolstered by fishing in Mifimbo through the direct or indirect exploitation of Kanakashi Island residents, chiefs are forced to choose between maintaining allegiance to government policies and protecting the short and long-term economic interests of their subjects. For several traditional authorities, the choice is clear. Despite projecting a public façade in support of legal mandates as they pertain to Mifimbo, Mwata Kambwali stalwartly defended Kanakashi residents against government attempts to evict them in $2004{ }^{18}$ The Mwata Kambwali and Potolo residents have maintained a close relationship since the current Kambwali's investiture in 2002. This relationship includes frequent gifts of fish from the island to the palace, regular visits, and an annual Zkw 500,000 (Zambian kwacha) (US\$100) contribution from Potolo Village to the Mutomboko Ceremony, funneled through the Kambwali Palace. ${ }^{19}$ Previous interjections against government initiatives to remove settlers also occurred in 1994 and 1998. In the latter, Mwata Kazembe Munona XVIII disagreed with removal of Kanakashi settlers and put the blame for the deterioration of the situation instead on the Department of Fisheries (B. Aarnink and C. Kapasa 1995).

\section{Conclusion}

This paper situates the controversy over residence on Kanakashi Island as a threefold challenge. In practice, these fishers test legal restrictions and co-management strategies as they attempt to elude legal prohibition against settlement through claim to autochthony and community formation. Ecologically, these islanders pose a threat to an otherwise resilient fishery by fishing in a breeding area, and by targeting specific fish stocks. Theoretically, it reveals the need to complicate scalar analysis and assumptions about local practice in political ecology. Kanakashi Islanders provide an example of ethnically heterogeneous community formation, which, through declared autochthony and well-played politics of co-management have so far have managed to solidify claim to marginal, but resource rich land.

Colonial narratives that presumed Malthusian population pressure on finite resources, and favored industrial scale resource extraction, initially structured the socio-political and legal waterscape of Kanakashi settlement. In the past fifteen years, the introduction of co-management ideology has altered the social, economic and political channels of fishing and trading. Despite the hopeful intentions that accompanied neoliberal reforms of democratization, decentralization, and market liberalization, practice rarely plays out in concert with expectations. I have tried to show that these political and economic changes in Mweru-Luapula, as embodied by the co-management model, did not manufacture greater representative democracy, but instead shifted scales of, and relationships to, power.

Perhaps the clearest voice stating the current inability of local powers to extend democratic participation and fair access to resources is himself a local. A headman from Isokwe, the legal fishing island adjacent to Kanakashi (Figure 1), called vehemently for a return of the government as fishery manager:

Despite what they may say, Kanakashi residents are only fighting to stay so they can access the rich resources found in the Mifimbo Fish Breeding Area. The government must move in to take full responsibility. Right now they are leaving it to the chiefs [to handle the situation]... There won't be any village here when fish finish. They are trying to find ways and means of filling their pockets with money. Me, I am very, very sensitive. They even show that they catch [confiscate illegal] nets. [At a meeting the week before that gathered all island headmen with the presiding Chief Kambwali] Headman Potolo of [Kanakashi Island] said, "We are protecting [the fish breeding area]; we are cultivating." No, that is not the answer. No, the government must move in. ${ }^{20}$

For him, it is not a matter of local control that is important, but resource access. This headman appears to be under no illusions that in practice co-management is merely a re-scaling of power and resource networks (J. C. Brown and M. Purcell 2005).

One of the central tenets of the Kanakashi Islander argument for residence is their claim to an autochthonous right to land. Meyer and Geschiere (1999) note an enormous groundswell in claims to autochthony in Africa and elsewhere since widespread neoliberal reforms were commenced two decades ago. Kanakashi Islanders provide yet another case study validating this observation. Autochthons are literally

\footnotetext{
${ }^{18}$ E.g. Letters from Mwata Kambwali to the Department of Fisheries, Nchelenge, September 21, 2004 and January 17, 2005. His superior, Mwata Kazembe Mpalumena confirmed this interference (Kafumbe 2005, interview, October 9, 2005, Mwansabombwe).

${ }_{19}$ Interview with Kambwali Palace Secretary and Kambwali Chief Justice, October 1, 2005, Potolo Village, Kanakashi Island. 500,000 Zambian Kwacha is worth approximately US\$140.

${ }^{20}$ Interview with a headman (who requests anonymity), October 1, 2005, Isokwe Island.
} 
"sons of the soil." This distinguishes them from those who fight for indigenous rights to land. Indigenous groups by-and-large codify their rights based on recognition from the state that has previously subsumed them politically and geographically. While autochthonous groups, such as the internally migratory Baka pygmies of Central Africa (A. Lenhardt 2006), are associated with a much broader and diffuse status and not necessarily a long occupation of particular localities (P. Geschiere and S. Jackson 2006). Theoretically, a lack of official application of rights can relegate the autochthon stateless (A. Lenhardt 2006), but practically, their employment of the fluid concept of autochthony will more likely be positive to their interests in accessing land.

Autochthony wields symbolic currency that endows those who use it with a special relationship to natural resources, while not mandating the legal-historical verification demanded of indigenous groups (M. Dove 2006). Further, neoliberal imperatives of political decentralization and democratization have, ironically, empowered non-democratic customary rulers with greater authority by reconfiguring the regional and state politics of scale (A. Larson and J. Ribot 2005). This is the case in the Mweru-Luapula fishery under de facto co-management. Rather than meeting the interests of government and NGOs, the chiefly beneficiaries of this recent enhancement of power in the name of local conservation have, instead, buttressed the campaign of those living on Kanakashi to maintain their-at best-tenuous legal residence on a prohibited island.

\section{References}

\section{Selected Interviews by the Author}

Interview with Frederick Kafumbe, former Provincial Department of Fisheries Director, August 25, 2004, Mansa.

Interview with Headman Shinjoni, September 6, 2004, Kashikishi.

Interview with Robarm Mwape and Lameck Mwila, September 9, 2004, Kashikishi.

Interview with Headman Kashilu, November 15, 2004, Nchelenge.

Interview with Mupaka Diamond, November 26, 2004, Chitondo Village.

Interview with Derrick Kahinda, local fish trader, September 17, 2005, Nchelenge.

Interview with Kambwali Palace Secretary and Kambwali Chief Justice, October 1, 2005, Potolo Village, Kanakashi Island.

Interview with a headman, October 1, 2005, Isokwe Island.

Interview with Fannuel Mwela, Vice-Chairman Traditional Village Management Committee, October 2, 2005, Potolo Village, Kanakashi Island.

Interview with Mwata Kambwali, October 7, 2005, Kambwali Village.

Interviews with Mwata Kazembe, October 9-10, 2005, Mwansabombwe

\section{Bibliography}

Aalst, $\mathrm{H}$.

1999. Co-management of the Mweru Luapula Fishery: A Conservation and Management Action Plan to Implement a Community Based Integrated Management System. Nchelenge: Department of Fisheries (DoF).

Aarnink, B.H.M.

1996. The Fish Trade \& Tax Base of Lake Mweru: An Analysis of the Mweru Fish Trade based on a survey conducted at the Council Fish Barrier in Nchelenge in October \& November 1995. Nchelenge: Department of Fisheries.

Aarnink, B.H.M. and C.K. Kapasa.

1995. Report on the Meeting with Chiefs, Local Leaders, Fishermen Associations and Fisheries Staff on Mifimbo, Kalungwishi and Mwatishi Breeding Areas, held on $24^{\text {th }}$ of November 1994. Nchelenge: Department of Fisheries.

Annear, C.M.

2006. Legislating 'Liverpool': The Role of Law in the Development and Conservation of the Mweru-Luapula Fishery, Zambia. In Africa's Challenge: Using Law for Good Governance and Development, eds. A. Seidman, R.B. Seidman, P. Mbana, and H.L. Hanson, pp. 177-212. Trenton, NJ: Africa World Press, Inc. 
Bos, A.R., Kapasa, C.K., and P.A.M. Zwieten.

2006. Update on the bathymetry of Lake Mweru (Zambia), with notes on water level fluctuations. African Journal of Aquatic Science 31: 145-50.

Brown, J.C. and M. Purcell.

2005. There's Nothing Inherent about Scale: Political Ecology, the Local Trap, and the Politics of Development in the Brazilian Amazon. Geoforum 36: 607-624.

Brox, O.

1990. Common Property Theory: Epistemological Status and Analytical Utility. Human Organization 49: 227-35.

Carey, T.G. 1965.

Lake Mweru-Luapula. In The Fish and Fisheries of Zambia, ed. M.A.E. Mortimer, pp. 62-8. Lusaka: The Government Printer.

Central Statistical Office, Zambia.

2004. 2000 Census of Population and Housing: Luapula Province Analytical Report, Volume Four. Lusaka: Central Statistical Office.

Charles, A.T., Brainerd, T.R., Bermudez, A.M., Montalvo, H.M., and R.S. Pomeroy.

1993. Fisheries Socio-economics in the Developing World: Regional Assessments and Annotated Bibliography. Ottawa: International Development Research Centre.

Chongo, B., Lubilo, R., and E. Simpungwee.

1995. A Study On The Mweru-Luapula Fishing Associations. Nchelenge: SNV (Netherlands Development Organisation).

Crowe, B.L.

1969. The Tragedy of the Commons Revisited. Science 166: 1103-7.

Department of Fisheries, Zambia.

1995. Annual Report for 1995: Landing Records for Chipita, Kashikishi, Isabi Investments, and Chani Fisheries. Nchelenge: Department of Fisheries.

Department of Fisheries, Zambia.

1995. Fisheries Management Mweru-Luapula: Towards a Solution of the Mifimbo Problem. Nchelenge: Department of Fisheries.

Dietz, T., Dolak, N., Ostrom, E., and P.C. Stern.

2002. The Drama of the Commons. In The Drama of the Commons, eds. E. Ostrom, T. Dietz, N. Dolak, P.C. Stern, S. Stonich, and E.U. Weber, pp. 3-35. Washington D.C.: National Academy Press.

Dove, M.R.

2006. Indigenous People and Environmental Politics. Annual Review of Anthropology 35: 191-208.

Fauchereau, N., Trzaska, S., Rouault, M., and Y. Richard.

2003. Rainfall Variability and Changes in Southern Africa during the 20th Century in the Global Warming Context. Natural Hazards 29: 139-54.

Feeny, D., Berkes, F., McCay, B.J. and J.M. Acheson.

1990. The Tragedy of the Commons: Twenty Years Later. Human Ecology 18(1): 1-19.

Geschiere, P. and S. Jackson.

2006. Autochthony and the Crisis of Citizenship: Democratization, Decentralization, and the Politics of Belonging. African Studies Review 49(2): 1-7.

Gordon, D.M.

2003. Technological change and economies of scale in the history of Mweru-Luapula's fishery (Zambia and Democratic Republic of Congo). In Management, Co-management or no management? Major dilemmas in southern African freshwater fisheries: Case Studies, eds. E. JulLarsen, J. Kolding, R. Overa, J. Raakjaer Nielsen, and P.A.M. Zwieten. Rome: FAO.

Gordon, D.M.

2005. Growth without Capital: A Renascent Fishery in Zambia and Katanga, 1960s to Recent Times. Journal of Southern African Studies 31: 495-511.

Gordon, D.M.

2006. Nachituti's Gift: Economy, Society, and Environment in Central Africa (Africa and the Diaspora). Madison, WI: University of Wisconsin Press. 
Goudswaard, K.P.C.

1999. A dynamic fishery in Zambia: A case of change in the Mweru Luapula Fishery, Report of a frame survey in 1997. Nchelenge: Department of Fisheries.

Hardin, G.J.

1968. The Tragedy of the Commons. Science 162: 1243-8.

Hulme, M., Doherty, R., Ngara, T., New, M., and D. Lister.

2001. African climate change: 1900-2100. Climate Research 17: 145-68.

Jul-Larsen, E., Kolding, J., Overa, R., Raakjaer Nielsen J., and P.A.M. Zwieten.

2003. Management, co-management or no management? Major dilemmas in southern African freshwater fisheries: Case studies. FAO, Rome.

Jul-Larsen, E. and P.A.M. Zwieten.

2002. African Freshwater Fisheries: What Needs to be Managed? WorldFish Center Quarterly 25: 35-40.

Kafumbe, F.S.

2005. Proceedings on the Mwata Kazembe's In-House Meeting with the Mwata Kambwali, Subchief Muyembe, Fishing Village Heads and Counsellors on Mifimbo Breeding Area: Held on March 14-16, 2005 at Kazembe. Mansa: Department of Fisheries.

Larson, A.M. and J.C. Ribot.

2005. Democratic decentralisation through a natural resource lens: an introduction. In, Democratic Decentralisation through a Natural Resource Lens, eds, Ribot, J.C. and A.M. Larson. London: Routledge, pp. 1-25.

Lenhardt, A.

2006. Baka and the Magic of the State: Between Autochthony and Citizenship. African Studies Review 49(2): 69-94.

Lubilo, R., Maangwe, V., and F. Lubasi.

1993. Report on the Fish Conservation Seminar for Mweru Luapula Fishers and Traditional Chiefs Held in October 1992. Nchelenge: Department of Fisheries.

Marshall, N., Adrasola, L., Griffin, J., Lampe, H.C., and R.B. Pollnac.

1975. Artisan Fisheries: Characteristics, Problems, Needs, and Relationships to Aquaculture. Kingston: University of Rhode Island.

McCay, B.J.

1995. Common and private concerns. Advances in Human Ecology 4: 89-116.

McCay, B.J.

1996. Common and private concerns. In, Right to Nature: Ecological, Economic, Cultural, and Political Principles of Institutions for the Environment, eds, S. Hanna, C. Folke, K.G. Maler, pp. 111-26. Washington, DC: Island Press.

McCay, B.J., and J.M. Acheson, eds.

1987. The Question of the Commons: The Culture and Ecology of Communal Resources. Tucson: University of Arizona Press.

Meyer, B. and P. Geschiere, eds.

1999. Globalization and Identity: The Dialectics of Flow and Closure. Oxford: Blackwell Press.

Musambachime, M.C.

1987. Rural Political Protest: The 1953 Disturbances in Mweru-Luapula. The International Journal of African Historical Studies 20: 437-53.

Ostrom, Elinor.

1990. Governing the Commons: The Evolution of Institutions for Collective Action. Cambridge: Cambridge University Press.

Pauly, D.

1994. On Malthusian Overfishing. In, On the Sex of Fish and the Gender of Scientists: Essays in Fisheries Science, ed, D. Pauly, pp. 112-7. London: Chapman \& Hall.

Pauly, D.

1997. Theory and Management of Tropical Multispecies Stock: A review, with emphasis on the Southeast Asian demersal fisheries. Manilla: ICLARM. 
Rappaport, R.

1984. Pigs for the Ancestors: Ritual in the Ecology of a New Guinea People. New Haven: Yale University Press.

Singleton, S.

1998. Constructing Cooperation: The Evolution of Institutions of Comanagement. Ann Arbor: University of Michigan Press.

Vayda, A.P. and R. Rappaport.

1968. Ecology, Cultural and Non-Cultural. In, Introduction to Cultural Anthropology, ed. J.S. Clifton, pp. 477-97. Boston: Houghton-Mifflin.

Zwieten, P.A.M, Aarnink, B.H.M, and C.K. Kapasa.

1995. How diverse a fishery can be!: Structure of the Mweru-Luapula fishery based on an analysis of the frame survey, 1992 and a characterization of the present management strategies. Nchelenge: Department of Fisheries.

Zwieten, P.A.M., Goudswaard, P.C., and C.K. Kapasa.

2003. Mweru-Luapula is an open exit fishery where a highly dynamic population of fishermen makes use of a resilient resource base. In, Management, Co-management or no management? Major dilemmas in southern African freshwater, eds, E. Jul-Larsen, J. Kolding, R. Overa, J. Raakjaer Nielsen, P.A.M. Zwieten. Rome: FAO.

Zwieten, P.A.M., Kapasa, C.K.

1995. Lake Mweru Luapula. Analysis of the Gillnet Survey 1994. Nchelenge: Department of Fisheries.

Zwieten, P.A.M., Kapasa, C.K. 1996. Lake Mweru-Luapula. Analysis of the Gillnet Surveys of 1982 to 1985 and 1994 to 1996. Nchelenge: Department of Fisheries.

\begin{abstract}
In theory, natural resource governance through co-management promises a rich array of benefits for local populations, from representative decision-making to legitimately equal and open access to natural resources. Anthropologists, social geographers and other practitioners of political ecology will not be surprised to learn that such theory rarely bears out in practice, but that instead sociopolitical relationships are forged in the niches created by reoriented power structures. These reconfigured relationships exhibit not only shifts in peer networks but also in relationships of scale, for example, among local fishers and chiefs, and chiefs and government agents. Recent application of a co-management system of enforcement in the Zambian portion of the Mweru-Luapula fishery shows how well-intentioned policy fails to produce expected results: leading to spoils for some and reduced value of access for others. This paper focuses on one among several case studies derived from this region. It describes how a small group of roughly fifty lake island residents gain advantage from the dubious legality of their incursion into a perpetually closed fish breeding area because, while legislative statute restricts all fishers from these fecund common-pool resource grounds, comanagement empowers "traditional" modes of authority with the de facto clout to rebuff civil officers charged with evicting these potentially destructive occupants. For their part, the recent immigrant squatters argue a moral imperative to residence by claiming autochthony. By doing so they leverage the comanagement prerogative intended to protect indigenous rights, while bolstering their own campaign to entrench themselves in the most valuable waters of the fishery.
\end{abstract}

Keywords: co-management, fishery, commons, autochthony, Zambia, Mweru-Luapula fishery, Kanakashi Island 


\section{Resumen}

En teoría, el control de recursos naturales a través de co-administración promete una rica multitud de beneficios para poblaciones locales, desde toma de decisiones representativas hasta acceso legítimamente igual y abierto a recursos naturales. Antropólogos, geógrafos sociales y otros profesionales de ecología política no se sorprenderán al escuchar que tal teoría rara vez se sostiene en la práctica, pues en su lugar las relaciones sociopolíticas son forjadas en los nichos creados por estructuras de poder reorientadas. Estas relaciones reconfiguradas exhiben no sólo cambios en redes semejantes sino que también en relaciones de escala, por ejemplo, entre pescadores locales y jefes, y entre jefes y agentes de gobierno. La reciente aplicación de un sistema de co-administración para hacer cumplir la ley en la porción Zambiana de la zona pesquera Mweru-Luapula muestra como políticas bien intencionadas fallan en producir los resultados esperados: llevando a pérdidas para algunos y a valor reducido de acceso para otros. Este artículo se enfoca en uno entre varios estudios de casos derivados de esta región. Se describe cómo un grupo pequeño de aproximadamente cincuenta residentes isleños de un lago obtienen ventaja de la dudosa legalidad de su incursión en un área de reproducción de peces permanentemente cerrada porque, mientras un estatuto legislativo restringe a todos los pescadores de esta fecunda zona de recursos comunes, co-administración habilita modos "tradicionales" de autoridad con la de facto influencia para rechazar a oficiales civiles encargados de desalojar a estos ocupantes potencialmente destructivos. Por su parte, los recientes ocupantes ilegales inmigrantes en la zona argumentan un imperativo moral de residencia al reclamar autoctonía. De esta manera, ellos se apalancan en la prerrogativa de co-administración dirigida a proteger derechos indígenas, mientras refuerzan su propia campaña para atrincherarse en las aguas más valiosas de la zona pesquera.

Palabras clave: co-administración, pesquera, recursos colectivos, escala, autoctonia, Zambiana, MweruLuapula pesca, Kanakashi Isla

\section{Résumé}

Théoriquement, la gouvernance des ressources naturelles a travers de co-gestion de la resources promesse pluiseurs avantages pour les populations locales; une gouvernance locaux, un égalité de droit et un libre accès aux ressources naturelles. Des anthropologues, des géographes sociaux et d'autres praticiens de "political ecology" ne seront pas surpris d'apprendre que cette théorie de co-gestion porte rarement dans la pratique, mais plutôt que des relations socio-politiques sont forgées dans les créneaux créés par les structures de pouvoir. Ces rapports présentent une reconfiguration non seulement l'évolution des réseaux sociaux, mais aussi dans les relations d'échelle, par exemple, parmi les pêcheurs locaux et les chefs, et les chefs et les agents du gouvernement. Après l'application récente d'un système de co-gestion et l'exécution dans la partie Zambienne du Mweru Luapula-pêche, nous montrons comment des politiques bien intentionnées ne parvient pas à produire les résultats escomptés: aboutissant à des avantages pour certains et la réduction de valeur de l'accès pour les autres. Ce document décrit une étude de cas provenant de Mweru Luapula. Il décrit comment un petit groupe d'une cinquantaine de résidents de lîle du lac tirer profit de la légalité douteuse de leur incursion dans une zone interdite pour la pêche, parce que, tandis que la législation restreint tous les pêcheurs de ces ressources lacustres. L'approche co-gestion donne le pouvoir à des autorités traditionnelles, qui contestent les fonctionnaires qui tentent de les expulser. La demande des "autochtones", en fait d'immigrants récents, pour avoir le droit de rester sur l'île et un impératif moral. Ce faisant, elles utilisent également l'approche de co-gestion pour leur propre avantage, car il est destiné à protéger les droits des autochtones. Dans le même temps, ils soutiennent leur campagne d'enchâsser dans la zone le plus valable pour la pêche.

Mots-clés: co-gestion, la pêche, terre communal, autochtonie, Zambie, Mweru Luapula, l'île Kanakashi 